\title{
Čtyři roky antropologicko-archeologického výzkumu v Tasově u Velkého Meziříćí
}

\author{
Josef Unger \\ Ústav antropologie Př́rodovědecké fakulty Masarykovy univerzity, Vinařská 5, 60300 Brno \\ Do redakce doručeno 10. června 2011; k publikaci přijato 21. řijna 2011
}

\begin{abstract}
VIER JAHRE ANTHROPOLOGISCH-ARCHÄOLOGISCHER FORSCHUNGEN IN TASOV BEI VELKÉ MEZIŘÍČÍ
ABSTRACT Bei den anthropologisch-archäologischen Forschungen im Areal heutiger Pfarre in Tasov (2007-2010) hat man festgestellt, dass die Pfarre aus frühgotischer Kirche aus der zweite Hälfte des 13. Jhdts überbaut war. Auf die Westseite hat man die Hälfte äleterer Rotunde aus dem ersten Viertel des 13. Jhdts. gefunden. Mit Rotunde und jüngere Kirche viele Gräber zusammmenhängen.
\end{abstract}

\section{SCHLÜSSELWÖRTER Kirche; Rotunde; Anthropologie; Mittelalter; Tasov}

\begin{abstract}
ABSTRAKT V rámci školního antropologicko-archeologického výzkumu areálu dnešní fary v Tasově (2007-2010) bylo zjištěno, že fara byla přebudována z raně gotického kostela sv. Jiří z druhé třetiny 13. století. Sondáží se podařilo zjistit celý půdorys tohoto kostela. Na západní straně dnešní fary odkryl výzkum polovinu lodi starší rotundy z první čtvrtiny 13. století. S rotundou i mladším kostelem souvisejí četné hroby.
\end{abstract}

KLÍČOVÁ SLOVA kostel; rotunda; antropologie; středověk; Tasov

Jen málo obcí se může pochlubit tak velikým počtem památek na tak malém prostoru jako Tasov. Na okraji obce stojí, v jádru gotický, ale barokizovaný farní kostela sv. Petra a Pavla. V obvodu obce leží zrrícenina hradu Dub i zřícenina „Hrádek“ a nachází se zde i místo, kde stával románský kostel sv. Václava, několik soch a smírčí křižz. Nemůžeme také opomenout vilu, kde žil a působil tasovský rodák kněz a básník Jakub Deml. Z hlediska archeologie a antropologie je důležité, že se zde narodil učitel, paleontolog a archeolog Jan Knies, který se nesmazatelně zapsal do výzkumů v Moravském krasu. K těmto známým památkám však přibyla další, která svým významem je jistě nadregionální. Jedná se o románský kostel sv. Jiří, o jehož podobě ještě před několika lety neměl nikdo představu. Na stopu tohoto kostela přišel tasovský farář Pavel Kryl, když při opravě fary zjistil, že na jižní straně budovy se nachází zazděný pozdně románský, nebo románsko-gotický či raně gotický portál (obr. 1,2). Prostřednictvím archeologa Moravského zemského muzea v Brně Milana Salaše byl o nálezu informován Ústav archeologické památkové péče v Brně, který ve spolupráci s Ústavem antropologie Prrírodovědecké fakulty Masarykovy univerzity zde již v roce 2007 provedl zjištovací výzkum v rámci terénního cvičení, při němž si posluchači osvojují základy preparace, dokumentace a exkavace archeologických situací, především hrobů. Potvrdilo se, že dnešní farní budova v sobě ukrývá podstatnou část původního kostela známého dosud jen z písemných pramenů. Také se podařilo zjistit, že se kolem kostela intenzivně pohřbívalo, že je nutno všechny výkopové práce $\mathrm{v}$ areálu sledovat a také, že lokalita je vhodná pro školní výzkum. Jedná se zřejmě o kostel postavený někdy ve druhé třetině 13 . století a zaniklý v souvislosti s vybudováním nového vrcholně gotického kostela (kolem roku 1390), který slouží dodnes. Z toho vyplývá, že lidské ostatky jsou dosti dobře časově ohraničeny a mohou být velmi dobrým pramenem pro poznání populace žijící na Českomoravské vrchovině ve 13. a 14. století. Především také bylo možno počítat $s$ veškerou podporou faráře Pavla Kryla i obecního úřadu.

Roku 2008 archeologické práce pokračovaly a pod povrchem se podařilo odkrýt jihovýchodní roh kněžiště, takže bylo možno stanovit v podstatě celý půdorys kostela (obr. 3). Některé prozkoumané hroby obklopující kostel byly porušeny částečně dochovaným zdivem blíže neznámé budovy na jižní 


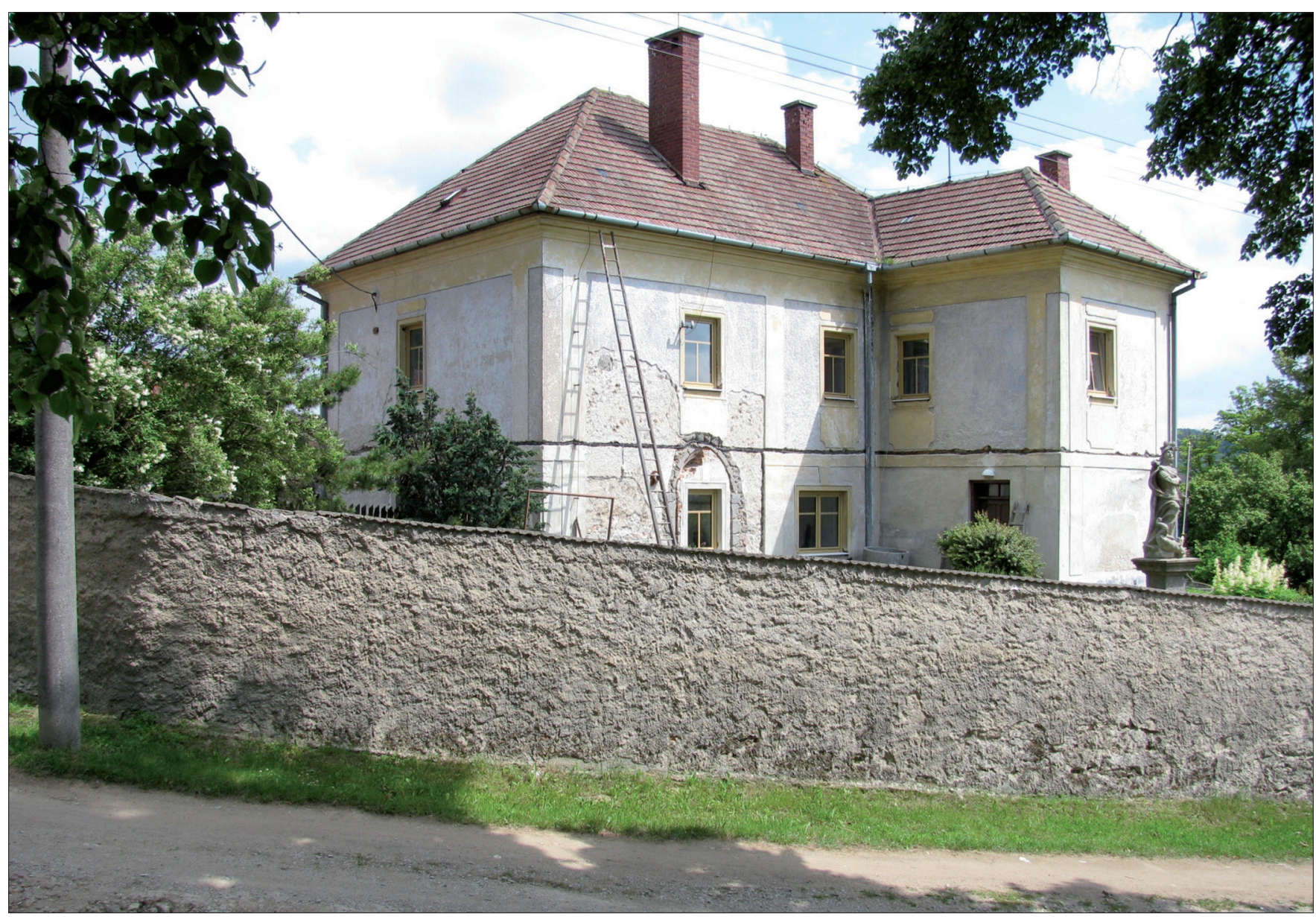

Obr. 1. Tasov. Fara od jihozápadu. Foto Josef Unger.

straně kněžiště, překryté vrstvou se zlomky keramiky ze 14 . století, zvířecími kostmi, železným nožem a visacím zámkem, jehož posouzení se ujal Vladimír Brych z Národního muzea v Praze. Celá situace byla překryta vrstvou navážkové hlíny, která obsahovala pražský groš ražený za vlády Vladislava II. kolem roku 1500, část dýmky a hrací kuličku. V závěru této výzkumné sezony bylo pod úrovní terénu na západní straně dnešní fary objeveno „podezřelé“ zdivo vybíhající západním směrem. Ke spolupráci na dokumentaci byl získán Stanislav Houzar z Moravské zemského muzea v Brně, který zhodnotil použitý stavební materiál po stránce petrografické a geologické s tím výsledkem, že stavební materiál je místního původu, ale horniny použité pro stavbu kněžiště kostela a horniny, z nichž byla stavěna ona bliže neznámá budova, se poněkud liší. Antropologickou analýzu tří hrobů provedl Lukáš Šín. Od května roku 2009 výzkum, jehož hlavním posláním bylo zajistit studentům antropologie terénní cvičení, pokračoval na dvou místech. Jednak na severní straně dnešní farní budovy byla položena sonda, která upřesnila polohu severovýchodního nároží kostelní lodi (obr. 4). Dále se na této straně vyrýsovala zed' navazující na kněžiště a porušující starší hrob. Zřejmě jde o zbytky sakristie připojené někdy ve 13. nebo 14 . století na severní straně ke kněžišti kostela. Kromě několika hrobů byla zde nalezena i drobná mince - brakteát (obr. 5) ražený za panování krále Přemysla Otakara II. (1253-1278) a zlomek okraje nádoby zhotovené $\mathrm{z}$ tuhového materiálu a na vnější straně zdobené ozubeným kolečkem - radélkem. Podobná keramika je na jižní Moravě datována do první poloviny 13. století (Procházka - Peška 2007, 219 ad.).

Naprosto nečekané zjištění však přinesla sonda položená podél západního průčelí fary. Nejdříve se zjistilo, že dvě rovnoběžné zdi vybíhající západním směrem mají méně zahloubenou základovou spáru než pozdější kostel. Dále toto zdivo bylo porušeno a př̀kryto hroby. Metr široká sonda vedená od fary západním směrem zachytila celou řadu vzájemně se porušujících kostrových hrobů jedinců pohřbených ve směru západ-východ. Teprve po jejich preparaci, dokumentaci a vyzvednutí došlo k tomu pravému překvapení, když se zjistilo, že zed' se stáčí a uzavírá kruh o průměru $5 \mathrm{~m}$. Není tedy pochyb o tom, že se jedná o asi 0,8 m široké základy rotundy, jejíž část i s apsidou leží pod budovou dnešní fary. Podle posudku Stanislava Houzara z Moravského zemského muzea jsou základy zbudovány z místního zvětralého a tedy sbíraného kamene, především tmavého žulosyenitu s menší příměsí aplitu, včetně ojedinělých kusů světlého migmatitu. Důkazem toho, že rotunda byla kostelem, kolem něhož se pohřbívalo, je objev čtyř kostrových hrobů porušených mladším zdivem. Vzájemná superpozice dvou hrobů nasvědčuje tomu, že doba, v níž se 


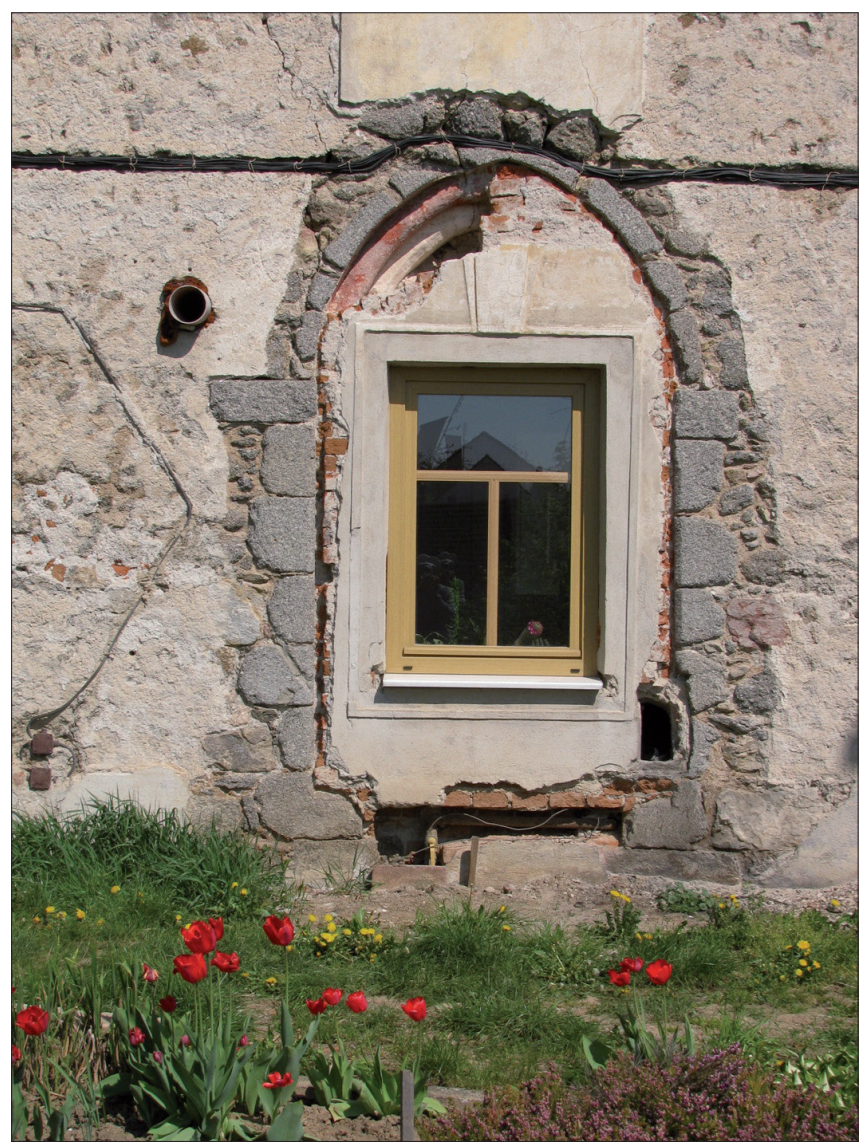

Obr. 2. Tasov. Zazděný a částečně odkrytý portál na jižní straně fary. Foto: Josef Unger.

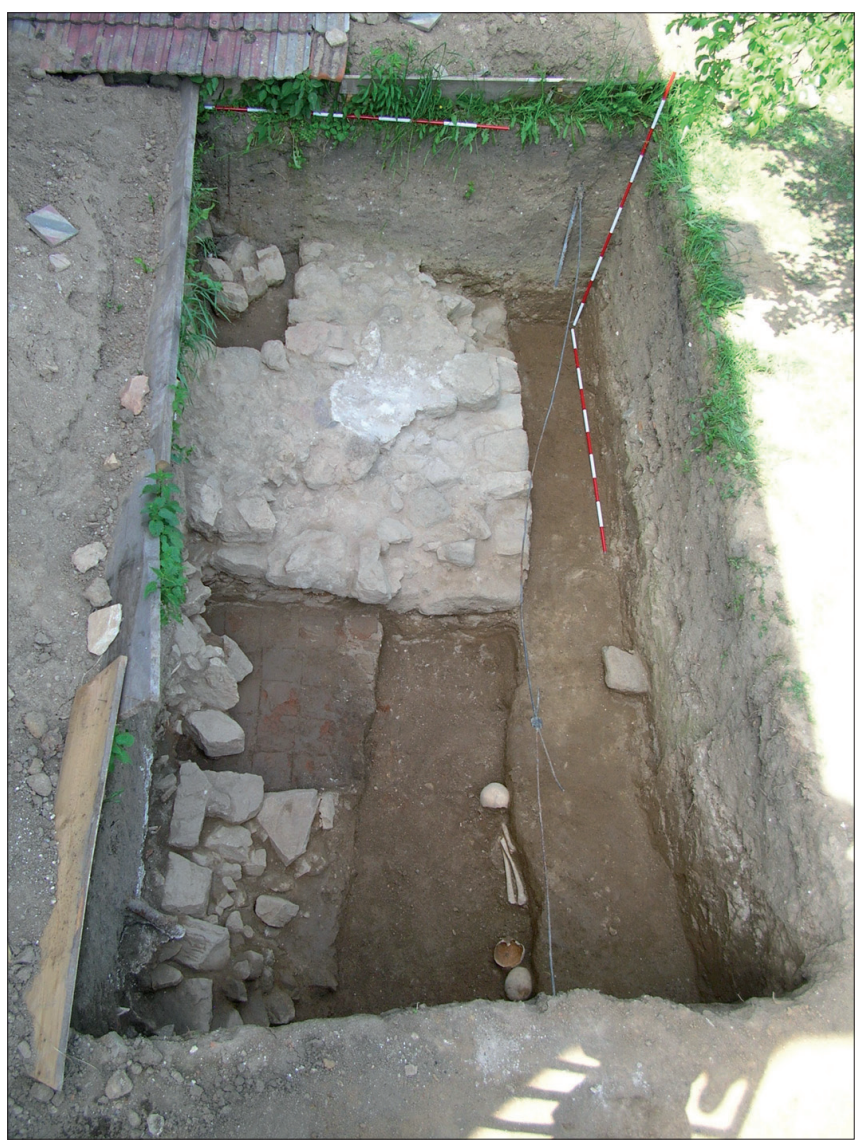

Obr. 3. Tasov. Jihovýchodní nároží kněžišš̌ kostela odkryté při archeologickém výzkumu. Foto: Josef Unger.

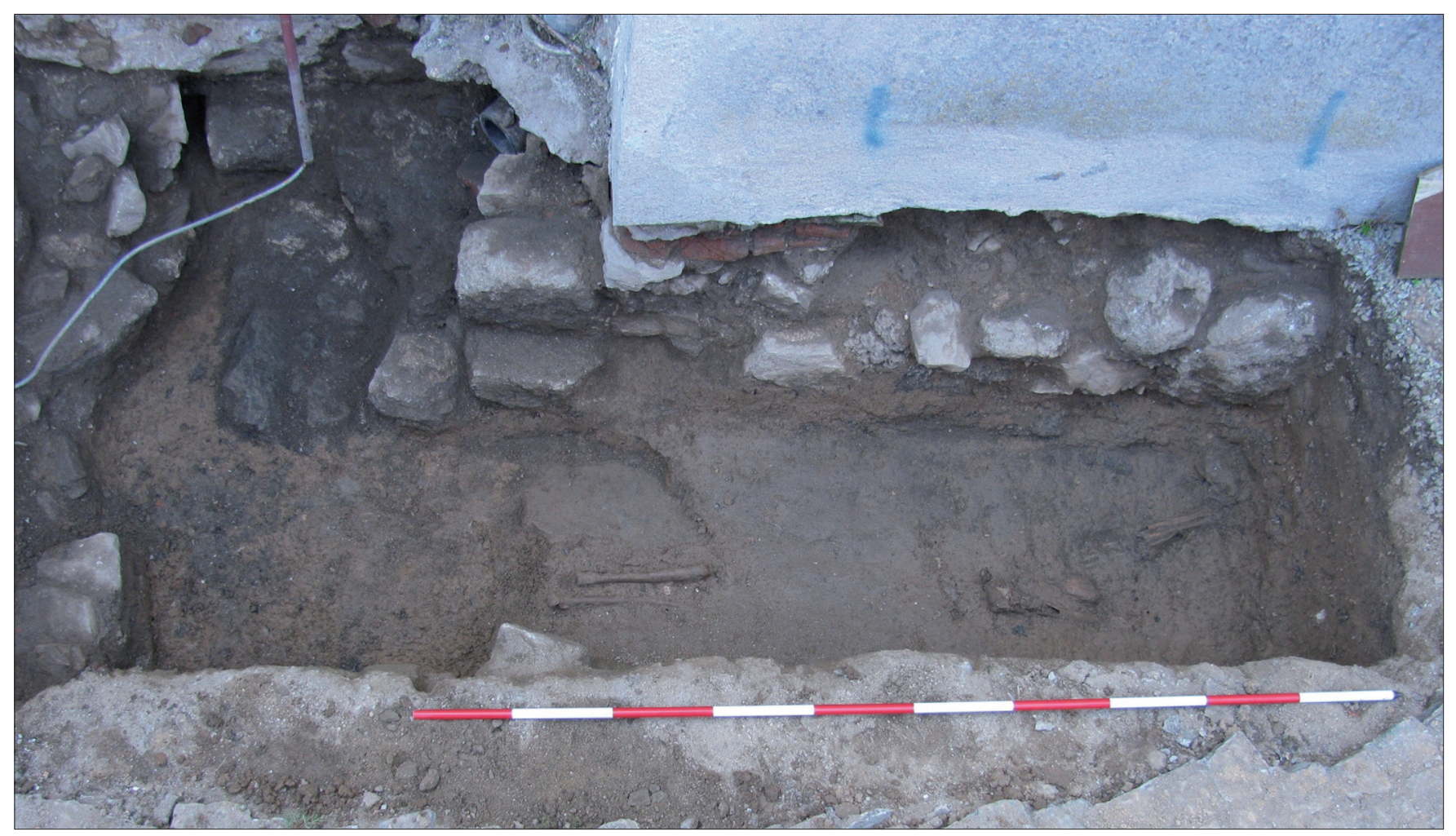

Obr. 4. Tasov. Severovýchodní nároží lodi kostela odkryté při archeologickém výzkumu. Foto: Josef Unger. 


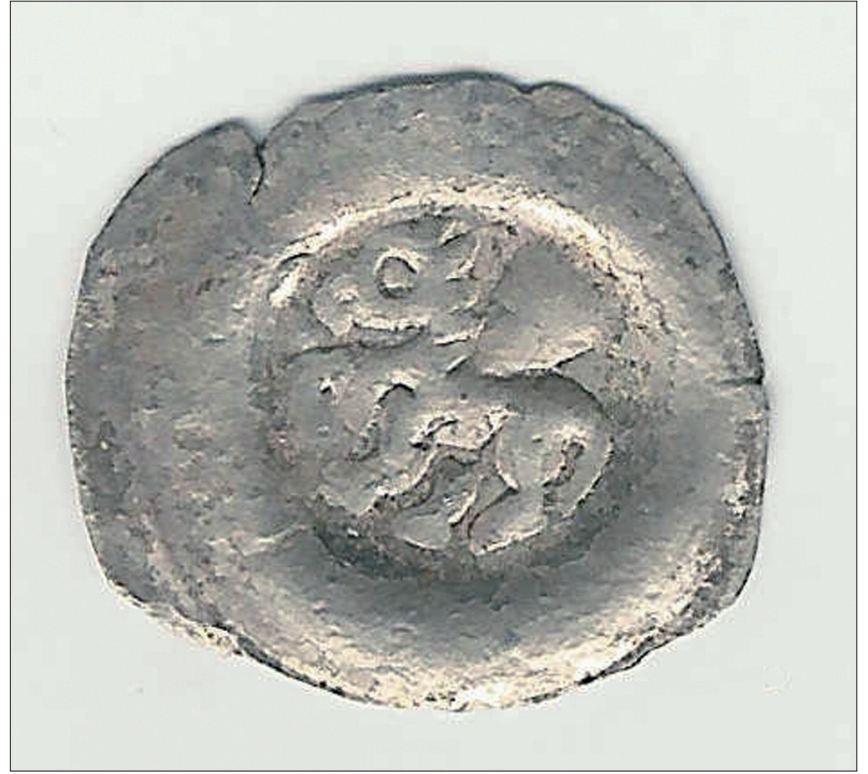

Obr. 5. Tasov. Brakteát Přemysla Otakara II. (1253-1278) nalezený v sondě na severní straně. Foto: Josef Havlát.

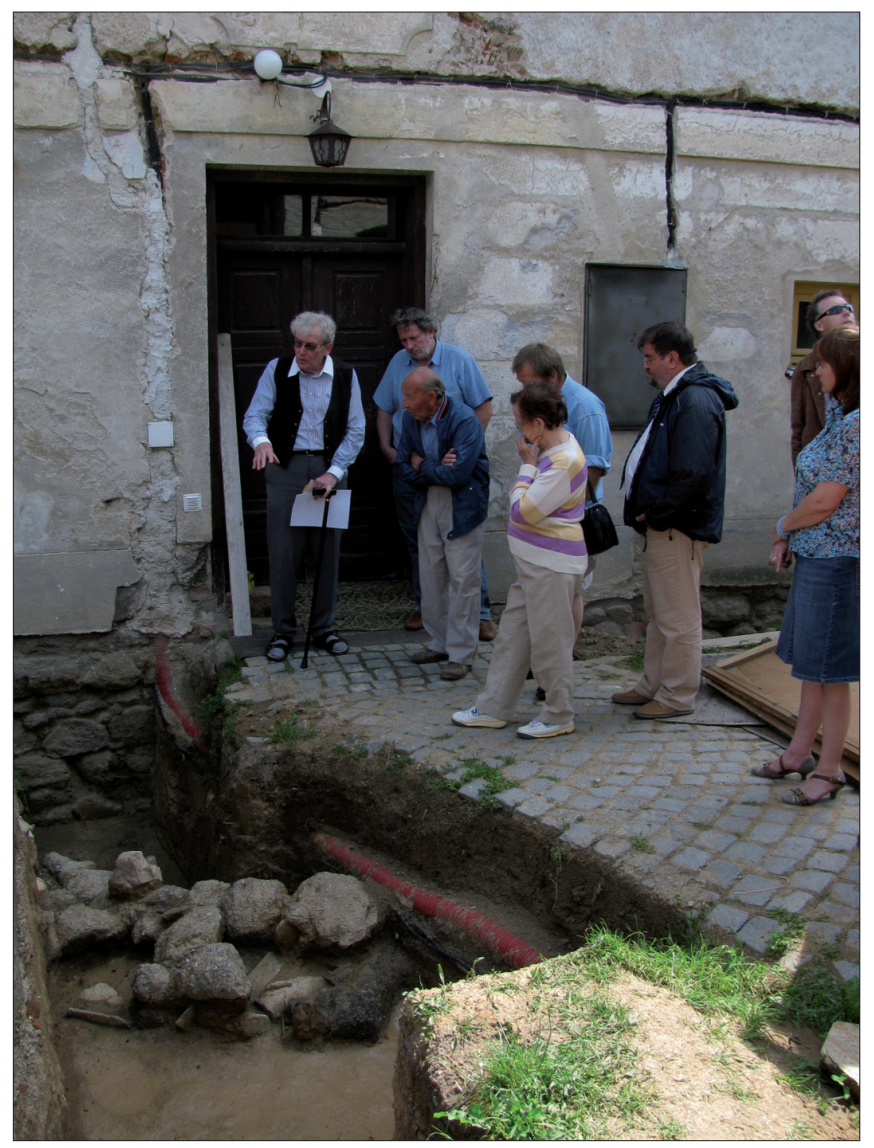

Obr. 6. Tasov. Účastníci odborné komise při prohlídce výzkumu. Foto: Martin Hotárek.

kolem rotundy pohřbívalo, nebyla nejkratší. Vzhledem k závažnosti objevu pozůstatků rotundy starší než byl raně gotický kostel, byla na 9. června 2009 svolána odborná komise, jejímž úkolem bylo posoudit tento objev a navrhnout další postup výzkumu a konzervace. Účast na komisi byla reprezentativní, protože se jí zúčastnili představitelé místní i krajské správy, Masarykovy univerzity, celé řady muzeí a památkových ústavů (obr. 6). Jednoznačně potvrdili význam objevu i datování nejpozději do první poloviny 13. století. Doporučili zpracovat a publikovat výsledky výzkumu, pokračovat dále ve výzkumu v souladu se stavebními úpravami a zajistit vhodnou prezentaci objevu přímo v terénu. V souvislosti s částečným odkryvem pozůstatků rotundy před západním okrajem současné fary (bývalý kostel sv. Jiří) bylo v interiéru provedeno doplňkové radarové měření, které mělo $\mathrm{v}$ poměrně omezeném prostoru za úkol dokreslit celkový půdorys rotundy skrytý pod podlahou. Naměřené hodnoty podle Vladimíra Haška svědčí o celkové západovýchodní délce rotundy včetně apsidy. Měření na dvoře severně od budovy fary a jižně na zahradě naznačují existenci dalšího zdiva i hrobů v těchto místech. Podstatným přínosem pro dokumentaci bylo geodetické zaměření okolí fary provedené firmou Geoding (Ladislav Dokulil, Vladimír Dobrovolný a Bohuslav Pohořilský). Objev rotundy i možnosti památkové prezentace byly předvedeny na mezinárodní konferenci v Bratislavě (Kryl - Unger 2010).

Roku 2010 pokračoval výzkum v souladu s doporučením komise odkryvem celé části půdorysu rotundy vně fary (obr. 7). Především bylo nutno vypreparovat, zdokumentovat a vyzvednout větší počet často vzájemně se porušujících hrobů, které byly součástí hřbitova obklopujícího kostel (obr. 8). Zemřelí zde byli pohřbíváni v poloze naznak ve směru západvýchod s hlavou k západu a s horními končetinami zkř́ǐ̌enými v pánvi, nebo položenými podél těla, či mírně pokrčenými v lokti. V hrobech se jen výjimečně našly přezky a železný nůž. Několik zlomků keramiky s příměsí tuhy a zdobených ozubeným kolečkem souvisí se samými počátky osídlení tohoto místa. Horninový materiál použitý ke zbudování základů rotundy byl znovu posouzen Stanislavem Houzarem, který konstatoval především př́tomnost navětralého tmavého žulosyenitu a v menší míře migmatitu a aplitu z nedalekého okolí. Po důkladné dokumentaci a geodetickém zaměření obvodu rotundy Ladislavem Dokulilem byla celá situace překryta geotextilií a zasypána.

Na základě dosavadního archeologického výzkumu se dějiny tohoto místa jeví následovně: V souvislosti s kolonizací Českomoravské vrchoviny byl nejpozději v první polovině 13 . století založen Tasov, u jehož zrodu byla šlechtická rodina, z níž k roku 1233 známe Záviše a dále až do roku 1240 ještě Mladotu, Bohuslava a Budislava, kteří se psali podle tohoto místa (CDB III, 50, 88, 165, 227; CDM II, 232, 249, 284, 316). Jednalo se o příslušníky rodu erbu křídla, kolonizujícího poříćí Oslavy a majícího také sídlo ve Velkém Meziř́ičí, kde snad již ve třicátých nebo čtyřicátých letech 13 . století stával hrad (Plaček 2001, 678-679; Měřínský 2008, 30-31). Tato rodina si patrně na nevýrazné ostrožně nad Tasovem vybudovala dvorec s vlastnickým kostelem - rotundou. Rotunda, pravděpodobně již tehdy zasvěcená sv. Jiří, byla opatřena farními právy, protože se kolem ní pohřbívalo. Vzhledem k malé šířce základů, a tedy i nadzemního zdiva, se jednalo o poměrně jednoduchou plochostropou stavbu. Apsida, zasahující pod 


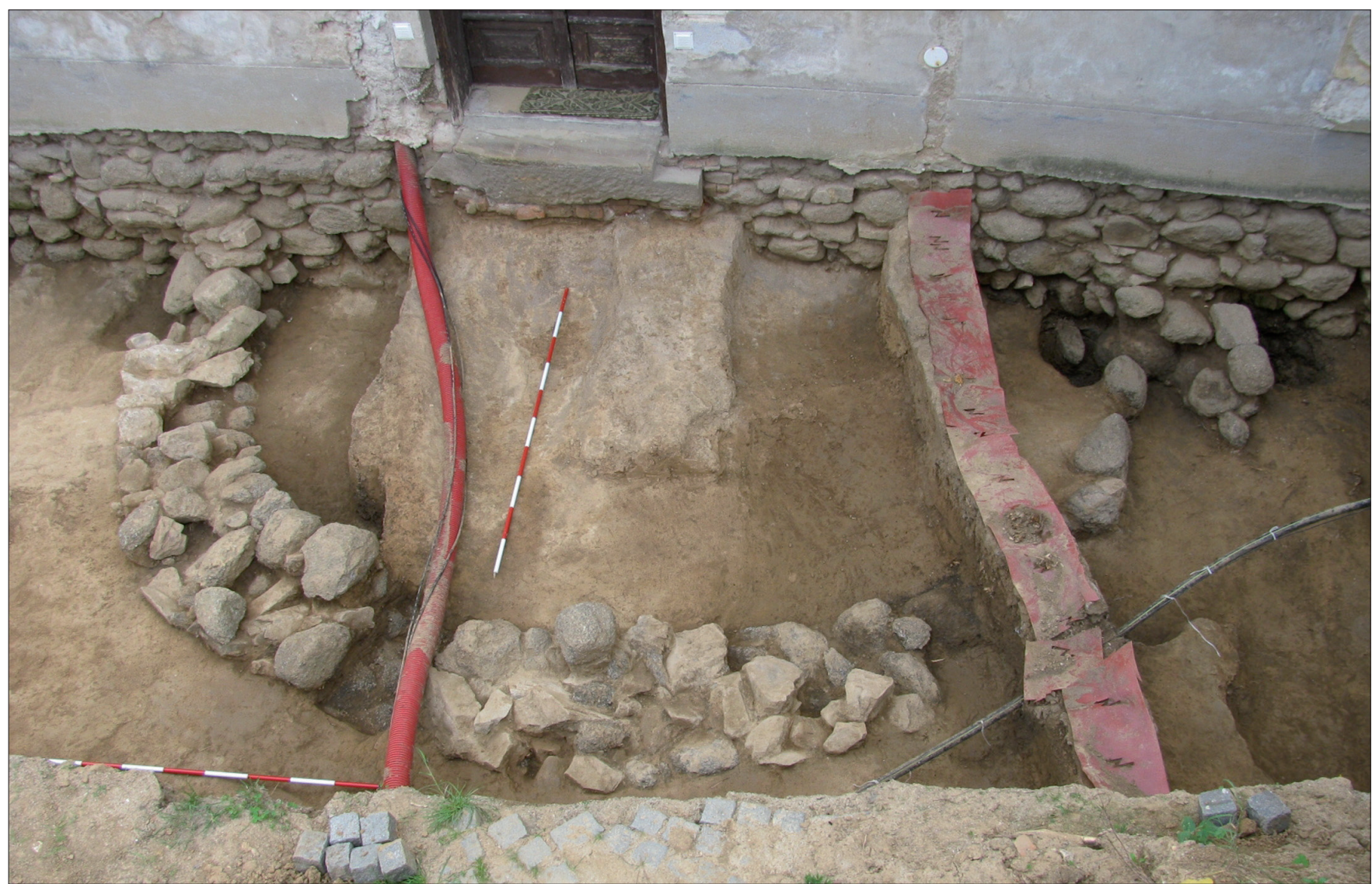

Obr. 7. Tasov. Část základů zdiva románské rotundy západně od fary. Foto: Josef Unger.

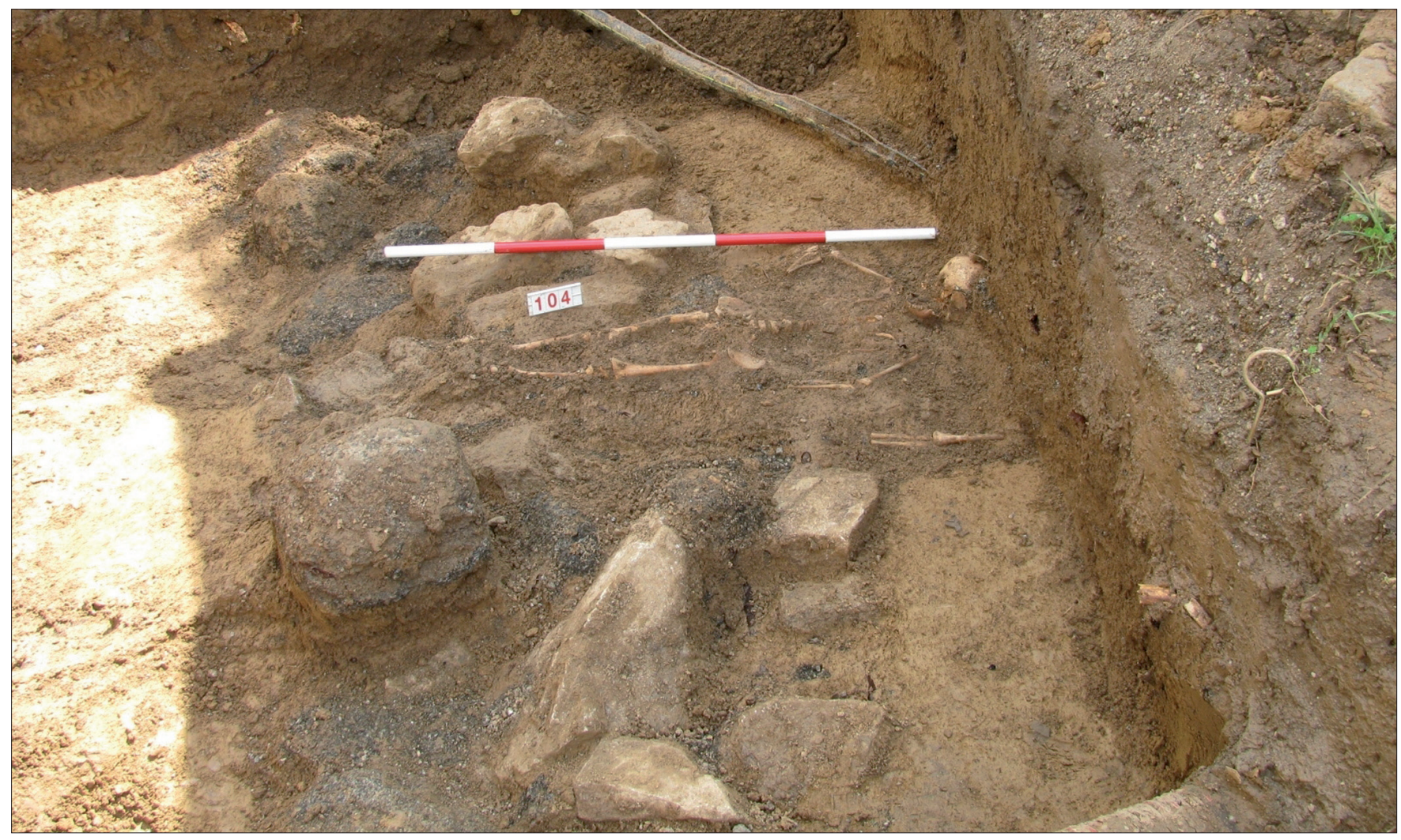

Obr. 8. Tasov. Hrob dítěte 104 překrývající zdivo rotundy. Foto: Josef Unger. 


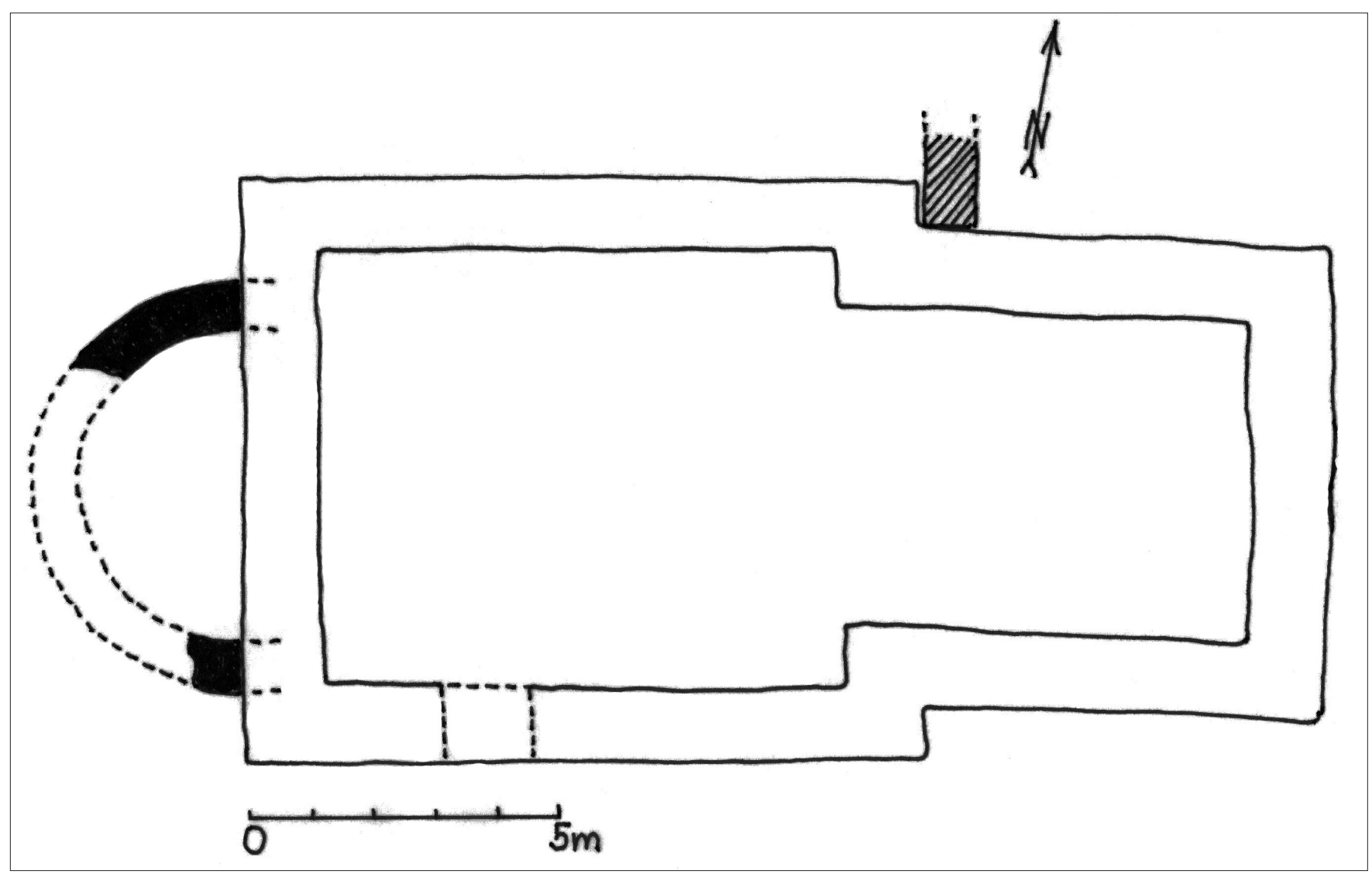

Obr. 9. Tasov. Půdorys kostela, části sakristie a části starší románské rotundy. Zaměřil Martin Hotárek.

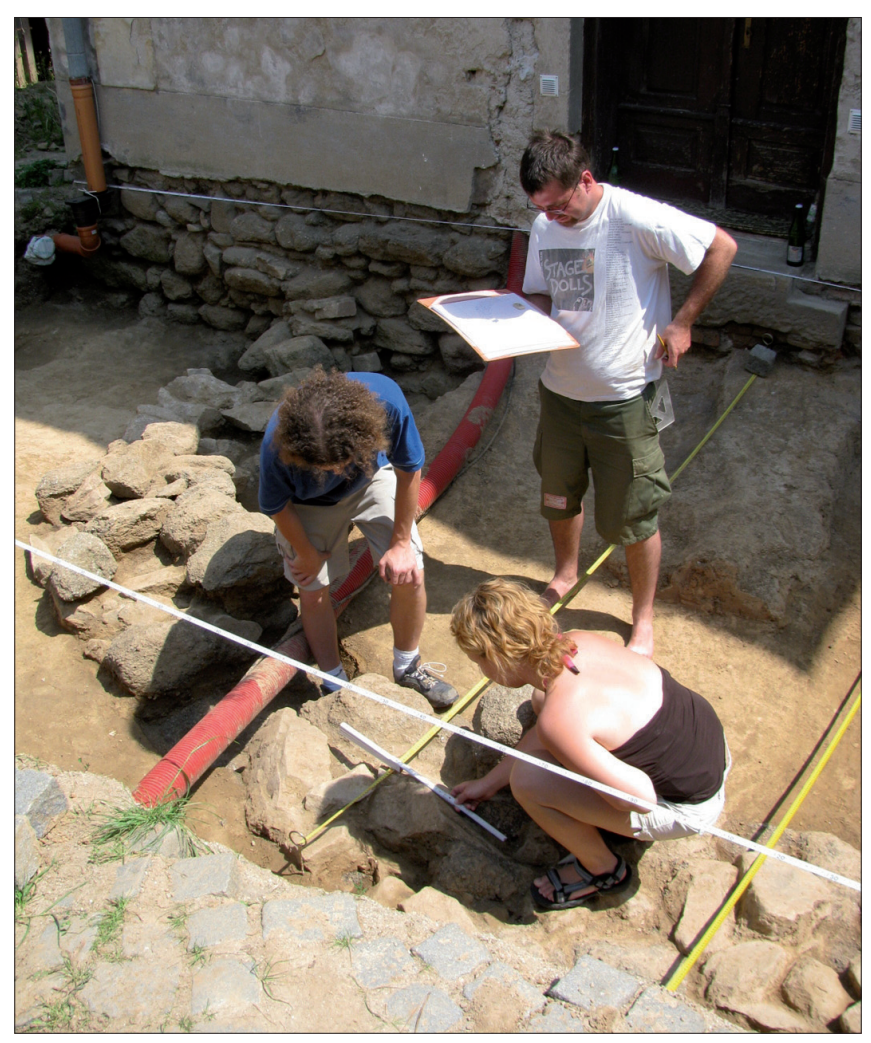

Obr. 10. Tasov. Studenti Ústavu antropologie Př́rodovědecké fakulty Masarykovy univerzity při dokumentaci zdiva rotundy. Foto: Josef Unger. budovu nynější fary, mohla mít hloubku o velikosti poloměru lodi (obr. 9). Někdy v druhé třetině 13. století se ukázalo, že původní stavba již nevyhovuje požadavkům kladeným na farní kostel, byla tedy zbourána a kámen, s výjimkou základů, byl použit na stavbu nového kostela sestávajícího z pravoúhlého kněžiště a obdélné lodi. Také kolem tohoto nového kostela, zřejmě nezměněného patrocinia, se intenzivně pohřbívalo, jak o tom svědčí množství vzájemně se porušujících hrobů. V té době stával v Tasově i další románský kostel zasvěcený sv. Václavovi; později (roku 1784) byl odstraněn. V letech 1970 až 1971 se na jeho místě stavěla budova Průmyslového zboží a při té př́ležitosti byly základy odkryty, ale bohužel nedokumentovány (Kudělka 1982-1983, 84-85). Existence dalšího románského dvorce u tohoto kostela je možná. Zřejmě koncem 14. století již ani zvětšený kostel sv. Jiří nevyhovoval a přičiněním Sazemy z Tasova došlo k vybudování nového vrcholně gotického kostela, který duchovním potřebám slouží v pozměněné podobě dodnes. Původní kostel sv. Jiří byl opuštěn a připomíná se k roku 1550 a 1561 jako pustý kostelík, který byl roku 1730 upraven na faru (Kratochvil 1907).

Rotunda jako stavební typ kostela se na Moravě uplatňuje od 9. století (Konečný 2005, 47-78). Oproti kostelům s podélnou osou se jedná o typ mnohem vzácnější s oblibou stavěný v souvislosti se sídly panovníků. Teprve od 12 . století bývaly rotundy budovány i předními velmoži. K známým rotundám šlechtického založení (Šebkovice, Častohostice, Štěpkov, Plaveč) přibyla tedy další rotunda v Tasově, která si zaslouží 


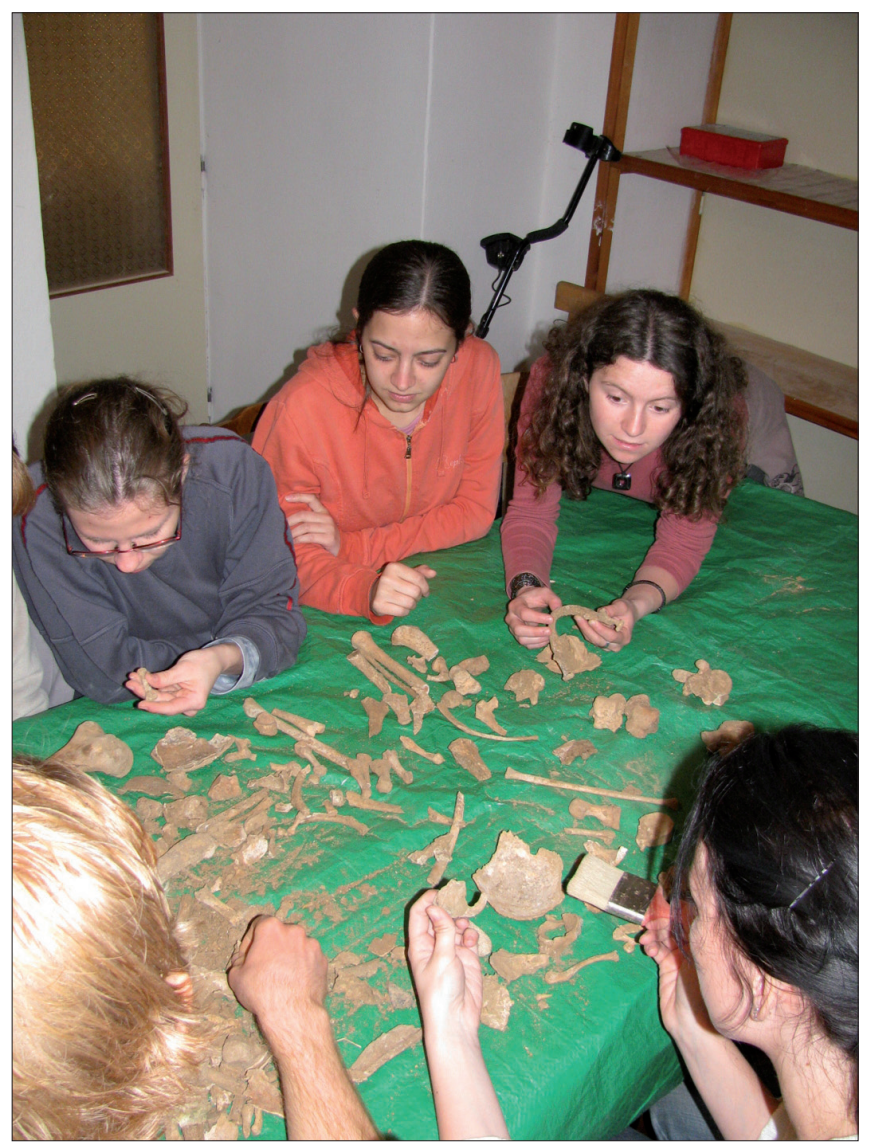

Obr. 11. Tasov. Studenti Ústavu antropologie Př́rodovědecké fakulty Masarykovy univerzity při tř́́dění antropologického materiálu. Foto: Josef Unger.

pozornost z hlediska památkové ochrany, archeologie, dějin umění i historie. Poměrně hodně práce si vyžádá zpracování výsledků výzkumů, které by měly vyústit v kresebnou a modelovou rekonstrukci obou nově objevených kostelů a také $\mathrm{v}$ půdorysné vyznačení objeveného zdiva přímo $\mathrm{v}$ terénu. Značné úsilí bude třeba při zpracování lidských kostí a jejich zařazení do širších souvislostí. Další objevy lze očekávat při stavebních úpravách fary a okolí.

Tasov zůstane asi navždy v mysli studentů, kteří se zúčastnili terénního výzkumu a mnohdy za nepříznivého počasí krok za krokem odkrývali situace hovořící přes propast staletí (obr. 10-12). Také občané Tasova a okolí, včetně školní mládeže, kteři se přišli podívat na každoroční výsledky výzkumu při dnech otevřených dveř́i, nahlédnutím do dávné minulosti svého bydliště jistě získávají k místu hlubší vztah. Výsledkem celého výzkumu by měla být kresebná či modelová rekonstrukce jak rotundy, tak i mladšího kostela, takže se opět prokazuje, že smyslem archeologického výzkumu v antropologickém pojetí není objevování trosek, ale života v minulosti.

\section{LITERATURA}

Konečný, Lubomír Jan (2005): Románská rotunda ve Znojmě. Brno.

Kratochvíl, Augustin (1907): Vel.-Meziříčský okres, Vlastivěda moravská. Brno.

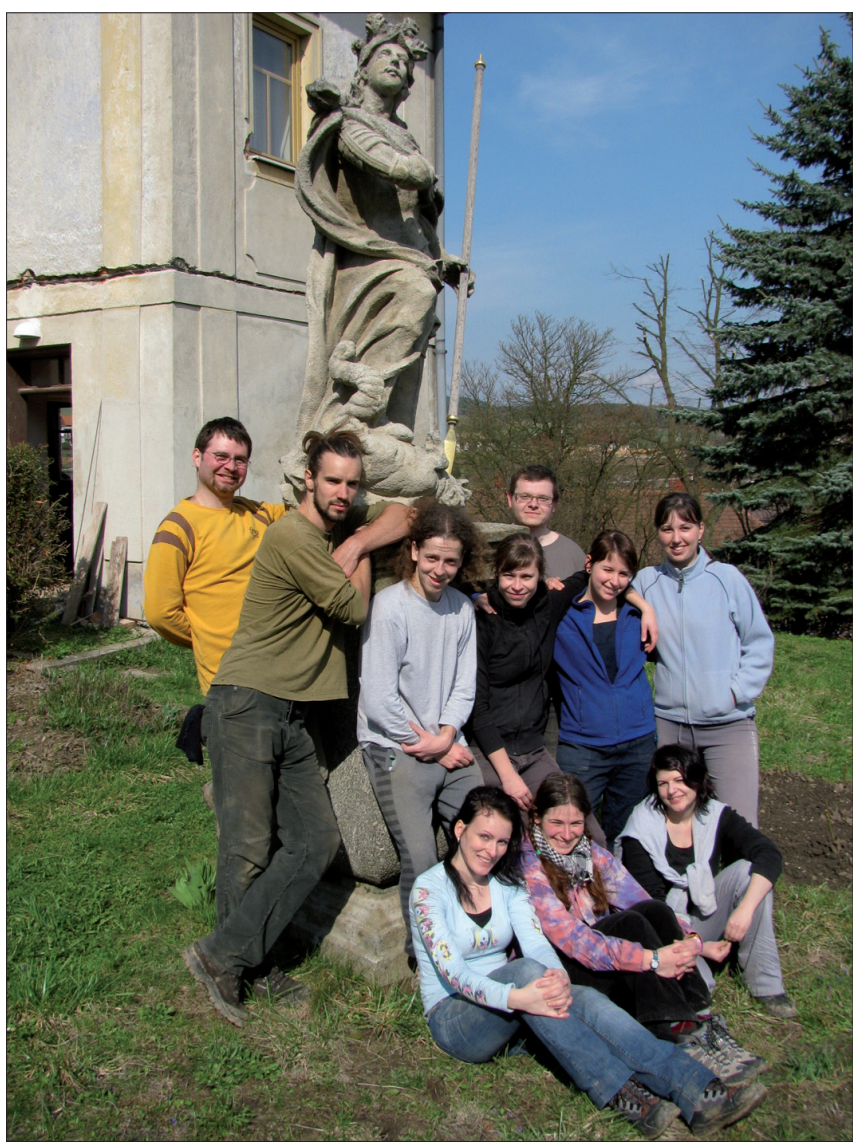

Obr. 12. Tasov. Účastníci výzkumu roku 2010 pod sochou sv. Jiř́i. Foto: Josef Unger.

Kryl, Pavel - Unger, Josef (2010): Archeologický výzkum a projekt prezentace románského kostela sv. Jiř́i v Tasově. Monumentorum tutela, 22, 107-114. Kudělka, Zdeněk (1982-1983): Výzkum románské architektury na Moravě III. Sborník prací Filozofické fakulty brněnské univerzity, F 26-27, 70-87. Měřínský, Zdeněk (2008): Osídlování krajiny a počátky města i hradu do roku 1415. In: Velké Meziřící v zrcadle dějin. Brno, 27-60.

Plaček, Miroslav (2001): Ilustrovaná encyklopedie moravských hradů, hrádků a tvrzí. Praha.

Procházka, Rudolf - Peška, Marek (2007): Základní rysy vývoje brněnské keramiky ve 12.-13./14. století. Přehled výzkumů, 48, 143-299.

\section{AUTOR}

Unger, Josef (11. 9. 1944, Brno), archeolog a sociokulturní antropolog, profesor Ústavu antropologie Př́rodovědecké fakulty Masarykovy univerzity. Ve výzkumné práci se zabývá především sídly a životem šlechty ve středověku, archeologií církevních objektů a antropologií pohřebního ritu. Vedl celou řadu terénních archeologických výzkumů (zaniklé vsi Topolany, Bořanovice, motte na zaniklé vsi Koválov, kostely v Mušově, Hustopečích, Brně, Tasově a na zaniklých vsích Divice, Narvice, Koválov, hrad v Lelekovicích, pohřebiště v Morkůvkách, Divákách). Člen redakční rady časopisů Archeologické rozhledy, Castellologia bohemica, Jižní Morava. Přednášel na univerzitách v Bambergu, Banské Bystrici, Bratislavě, Göttingen, Nitře, Olomouci, Opolí, Opavě, Poznani a Wrocławi. Kromě řady odborných studií je autorem monografíi: Pohořelice-Klášterka: Pravěké sídliště, slovanská osada a zaniklá středověká ves (Praha 1980), Hrádky a tvrze na Moravě (spolu s Vladimírem Nekudou, Brno 1981), Stře- 
dověké votivní předměty z Mušova (Mikulov 1984), Hrady na Pavlovských vrších (Mikulov 1985), Archeologické památky na okrese Břeclav (Mikulov 1988), Feudální sídlo z 13. století na zaniklé vsi Koválov u Žabčic (Brno 1989), Koválov: Šlechtické sídlo z 13. století na jižní Moravě (Brno 1994), Život na lelekovickém hradě ve 14. století: Antropologická sociokulturní studie (Brno 1999), Archeologie středovè$k u$. Odraz života lidí v archeologických pramenech (Hradec Králové 2008), Archeologie církevních památek na Moravě a ve Slezsku (Opava 2008), Religious Architecture in the Czech Republic in the Light of Geophysical Prospection and Archaeological Excavation (spolu s Vla- dimírem Haškem, Oxford 2010). Pro edici Panoráma biologické a sociokulturní antropologie napsal 9. svazek Pohřební ritus a zacházenís těly zemřelých $v$ českých zemích (s analogiemi i jinde v Evropě) $v$ 1.-16. století (Brno 2002) a 25. svazek Pohřební ritus 1. až 20. století $v$ Evropě z antropologicko-archeologické perspektivy (Brno 2005).

Kontakt: Prof. PhDr. Josef Unger, CSc., Ústav antropologie Př́rodovědecké fakulty Masarykovy univerzity, Vinařská 5, 60300 Brno, telefon: 549497 806, e-mail: unger@sci.muni.cz. 